\title{
ACCOUNTING STUDENTS' PERCEPTION AND THEIR INTENTION TO BECOME PROFESSIONALLY QUALIFIED ACCOUNTANTS
}

\author{
Dalilah Abdul Aziz ${ }^{* 1}$, Mohd Adha Ibrahim² ${ }^{2}$, Morni Hayati Jaafar Sidik ${ }^{1}$, Mazilena Tajuddin ${ }^{1}$ \\ Department of Accounting UniKL Business School Universiti Kuala Lumpur ${ }^{\text {I }}$, Faculty of Economics \\ and Muamalat, Universiti Sains Islam Malaysia ${ }^{2}$
}

\begin{abstract}
The purpose of this paper is to study accounting students at Majlis Amanah Rakyat (MARA) institutions $^{1}$ who are predominantly Bumiputra about their perception of the accounting profession, their grit level, the need for financial assistance and whether or not these are significant in influencing them to become professionally qualified accountants. The research was conducted using a questionnaire survey structured around seven independent variables and translated into 27 statements which was then distributed to accounting students at various MARA institutions. To analyse the data, descriptive and regression analysis were employed and the findings show that all predictor variables explain about 6.3 percent of the variability of students' intention to pursue professional qualification. The research results also show that when studying the independent variables individually, only three independent variables have significant relationship with students' intention to pursue professional qualification. These are job security or stability, financial assistance and grit. The findings have implications for accounting educators as well as the professional bodies and other related organisations in their effort to increase the number of professionally qualified accountants in Malaysia. The study also provides evidence that students' grittiness is a significant factor in influencing them to become professionally qualified accountants.
\end{abstract}

Keywords: Accounting, Students, Perception, Attitudes, Motivation, Accounting Education, Accounting Profession, Professional Qualification, Professional Qualified Accounta 


\section{INTRODUCTION}

Malaysia is striving to be a high income nation by the year 2020 and one of the main economic drivers of a high income nation is its financial markets. Therefore, in order to attract more investments, especially from foreign investors, the credibility of an entity's financial statements is essential. Useful financial reporting may help to ensure that the process of allocating capital for productive economic purposes will be done effectively. As such, professional accountants are needed to help achieve this goal (The Star, 2013). Malaysia will need to double its number of accountants to 60,000 by year 2020 to be able to sustain the nation's projected economic growth (New Straits Times, 2015). Existingly however, Malaysia is still struggling in attracting its graduates to pursue professional qualifications.

One of the initiatives made by the government of Malaysia to help increase the number of professional accountants is to provide a pool of potential candidates by offering diploma and degree in accounting through colleges and universities. However, most of the accounting graduates eventually opt to not pursue their professional qualifications; choosing to remain in jobs that do not require professional qualifications. It was reported that out of approximately 41,000 accountancy graduates from institutions of higher learning recognised by $\mathrm{MIA}^{2}$ since 1978 under Part 1 of the First Schedule, only 27\% of them became members of MIA (Committee to Strengthen the Accountancy Profession (CSAP), 2014). This percentage is low considering the fact that for these group of graduates to join as a member, they are only required three years of relevant working experience in the accounting field. This also suggests that accounting graduates may have deviated into non-accounting fields.

Additionally, only $8 \%$ of total professional accountants are Bumiputra (The Star Business News, 2015; Basaruddin, 2015). This significant under representation of Bumiputras in the accounting profession has sparked concerns amongst various stakeholders and as such, raising the need to determine the rationale behind the shortage.

The purpose of this research is to investigate the perception of the accounting students' towards pursuing professional qualifications; and in specific, students from Majlis Amanah Rakyat (MARA) institutions. Students from these institutions are mainly of Bumiputra ethnicity. In the following sections, a number of relevant previous studies are first presented which then leads into the research question and the conceptual framework. Subsequently, the research approach is dicussed and the results and findings are presented. The paper then concludes with a summary of key points.

\section{LITERATURE REVIEW}

In Malaysia, several studies have shown that the accounting profession is still popular amongst university students (Samidi and Tew 1995; Said, Ghani, Hashim and Mohd Nasir, 2004). A study by Samidi and Tew (1995) reported that majority future accounting graduates had chosen accounting as a profession. Said et al. (2004) and Ghani, Said, Mohd Nasir and Jusoff (2008) found that the accounting profession is ranked amongst the most preferred careers by the public and private university students. Unfortunately, despite their interest in the profession, not many especially the Bumiputra graduates have continued on to pursue professional qualifications. As such, this research aims to understand the incoherence.

\footnotetext{
${ }^{2}$ Malaysian Institute of Accountants.
} 


\section{Perception, extrinsic and intrinsic motivation}

A study conducted by Germanou et al. (2009) found that if a student has a positive perception of the accounting profession, he or she is more likely to pursue a profession in accounting. The finding shows Malaysian students with positive perceptions on the accounting profession are more likely to pursue an accounting career. In the study, perceptions are measured by three categories namely extrinsic, intrinsic prestige and social. Extrinsic category is represented by salary, security of job and physical environment at work place. Prestige is represented by opportunities for promotions, decision making and recognition and status in the eyes of others. Intrinsic is represented by the experience of learning new things, accomplishing something important and a concern for being free from imposed constraints in the work environment. Whilst social relates to items that are affective in nature. All four categories are significantly related with the Malaysian students but only the intrinsic and social categories are found to relate significantly with the English students. This finding suggests that physical retributions such as salary and benefits, opportunities for promotions, job security and status are important motivators to the Malaysian students.

Another study by Jackling, de Lange, Phillips and Sewell (2012) found that Australian students to be intrinsically driven when pursuing a career in accountancy compared to a group of international students which mainly consist of Asian students. Both findings seem to suggest that extrinsic factors are highly relevant to Asian students in pursuit of a career as accountants. Furthermore, Sugahara and Boland (2006) found accounting students value good advancement opportunities, high social prestige and high salary significantly higher than non-accounting students.

Although other studies have shown that intrinsic as well as extrinsic factors may motivate students to be a professional accountant, various studies especially ones involving Asian students found that they are consistently intrinsically motivated. Hence why this research is biased towards extrinsic motivation.

\section{Salary}

Abdullah and Zakaria (2006) conducted a study in two public universities in Malaysia and found expected future salary an important attribute for students intending to join public accounting firms. A study conducted by Ghani et al (2008) indicates that first year accounting students perceive salary as a major factor to make an accountant happy. However, this result is not supported in a study by Mustapha and Abu Hassan (2012) and Law (2010) which do not find salary to be a significant factor in motivating a student to pursue CPA career. Since the two earlier studies show support for salary and the two latter studies do not, this study seeks to investigate if salary is a relevant variable for students to be professional accountants.

\section{Job security and stability}

Many studies supports the significance of job security and stability to be a factor in students pursuing career as an accountants. A study by Mustapha and Abu Hassan (2012) among final year accounting students at a public university in Malaysia found job security and and stability to be positively and significantly related to the respondents choosing to be professional accountant. Abdullah and Zakaria (2006) also support job security as an important attribute for accounting students to join public accounting firms. In another study by van Zyl and de Villiers (2011), it is found that accounting major students rank availability of employment as one of the motivating factors to become chartered accountants. Similarly, Myburgh (2005) reports 
that students choose availability of employment as the most important benefit for pursuing a career as chartered accountants.

\section{Prestige or status}

Jackling et al (2012) conducted a study on Australian and international students mainly from China, Malaysia and Hong Kong and found that for both groups, prestige is a significant factor for students to continue into accounting profession. This finding is consistent with Mustapha and Abu Hassan (2012) and Germanou and Hasall (2009).

\section{Opportunity for advancement}

Abdullah and Zakaria (2006) found evidence that opportunity for advancement as the most important attribute for accounting students to join a public accounting firm especially among the male students. This finding is reinforced by Mustapha and Abu Hassan (2012) who also found that opportunities for advancement to be postively correlated to students' career choice as professional accountant.

\section{Advisory received}

Other elements that have been investigated are 'parental influence' (Law, 2010) and parent and teachers' influence (Myburgh 2005) on motivating factors for students to be professional accountants. Law (2010) found that 'parental influence' significantly contribute to predicting the career choice of accounting students in Hong Kong. While Myburgh (2005) study on first year accounting students at University of Pretoria, South Africa shows that advice given by significant family members and influence of school teachers were ranked amongst the top three sources of influence in the respondents' career decision making. Therefore, this study seeks to also examine the significance of family and educators influence in predicting accounting students' intention to pursue professional accounting profession.

\section{Financial assistance}

Other than extrinsic and intrinsic factors, another factor that has been reported to influence students' intention to pursue professional qualification is its cost. A report by the CSAP (2014) cites that one of the top reasons for graduates not to pursue professional accountancy qualification is due to its costly expense. Myburgh (2005) findings corroborates this. Both studies imply that cost of qualifying as a professional accountant is a factor perceived negatively by respondents. Therefore, this study tests the same amongst MARA accounting students.

\section{Grit personality}

Bacanli (2006) found support that personality characteristics influences career indecisiveness while Gunkel, Schlaegel, Langella and Peluchette (2010) opines personality traits have direct effect on students' career. Duckworth and Peterson (2007) propose one personal quality prominent in successful leaders is grit. Grit is defined as perseverance and passion for longterm goals. The authors developed a self-report questionnaire called the Grit Scale and in total six studies were carried out. Study 1, shows that adults with higher grit achieved higher education. This finding also suggests that the ability to stick to long-range goals makes 
completion of higher studies possible. Study 2, shows grit to be the only significant predictor of a person less frequently to change jobs. Study 3 tested if high school Scholastic Aptitude Test (SAT) scores are linked to the Cumulative Grade Point Average (CGPA) of undergraduates in an elite university. The finding indeed shows that grit is positively linked with higher CGPA and grit is associated with undergraduates who had lower SAT scores. Studies 4 and 5 selected first year US Military cadets as their respondents and both studies found respondents with higher grit are more likely to complete their first year training. Finally, study 6 proves that among participants of a national level spelling bee competition, children who are grittier achieved better performance by working harder and longer. The results of all six studies suggests that grit is an important factor for an individual to sustain through tough environments and to achieve higher level of success. A predicament which mirrors closely the nature of most professional qualifications.

Thus, this study seeks to provide an insight on the following question:

Do these seven independent variables together motivate an accounting student to be a professional accountant?

Based on the discussion and research question, the proposed research model is as follows:

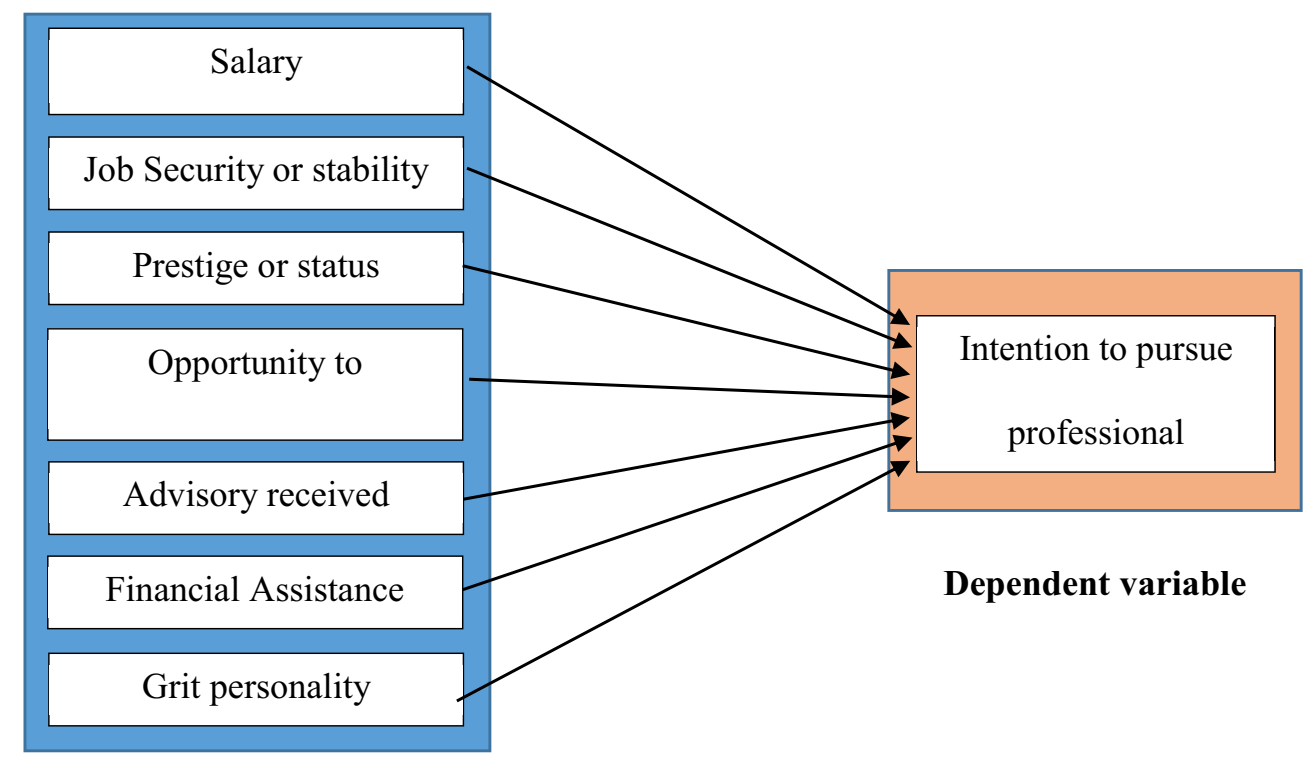

Figure 1: Conceptual Model

The model which has been adapted from the study by Mustapha and Abu Hassan (2012) shows that "Intention to pursue professional qualification" as the dependent variable and items such as salary, job security or stability, prestige or status, opportunity to advancement, advisory received, financial assistance and grit personality to be the independent variables for this study. 


\section{RESEARCH APPROACH}

This research is conducted to study the relationship between students' perception and their intention to pursue professional qualification. The approach taken is quantitative in nature and is in line with the positivism paradigm. The paradigm relies on deductive reasoning following a structured process leading to the identification of causal relationships, logical conclusions and the making of predictions according to various confidence levels (McKerchar, 2008).

The quantitative method was decided to be the most appropriate approach for this study in order to achieve the intended objectives. Although using more than one method may result in more rigorous outcome, other constraints have been considered. Ramenyi, Williams, Momey and Swartz (1998) suggest that the research approach should accommodate the research questions, costs, available budget, available time and target dates for completion, and skills of the researcher.

\section{Survey Research Design}

\section{Survey Method and Rationale}

There are various research methods in the quantitative approach that may be employed for this study such as the controlled experiment, content analysis, analysis of existing data, participant observation and survey (Babbie, 2013). The present study was undertaken by employing the questionnaire survey method. The main advantage of survey research is the reduced time and costs of carrying out the survey as compared to personal interviews (Babbie, 2013). This in turn allows a wide range of standardized information to be obtained from a large sample (Babbie, 2013). It enables respondents to complete the questionnaire in their own time and in a more convenient way compared to the face-to-face interview (Loo, 2006). Moreover, it is found to be the most reasonable method to cover a wide geographical area, to represent a given population (Loo, 2006). This method is also popular in social science studies and therefore it is also a method of empirical verification (Babbie, 2013) which can produce reliable measures.

\section{Survey Instruments}

The primary aim of the questionnaire is to examine the perception of the accounting students at MARA institutions in relation to their intention to pursue professional qualification. The questionnaire has four sections, A, B, C and D. Section A consists of questions on demographic information of the respondents such as institution, age, level of study, year of study, gender, ethnic, current CGPA, parent educational background and Sijil Pelajaran Malaysia (SPM) result for English paper. Respondents were asked to tick a box to answer each question or fill in the appropriate details as requested. This information is important to build the respondents' profile for this study and to determine the representativeness of the respondents in relation to the whole population. Section B is designed to collect information related to students' future plan after graduation. This section consists of four questions, one of which represents the dependent variable for this study ${ }^{3}$.

Additonally, sections C and D is developed to collect information in relation to students' perceptions of the accounting profession, advisory received, financial asisstance and their grit personality. There were 27 statements on students' perceptions and these were developed based

${ }^{3}$ Refer to Table 7, item **.

*Corresponding author's email: dalilahaa@unikl.edu.my 
on the conceptual model discussed earlier in Section 2. Using five-point Likert scales ( $1=$ strongly disagree to $5=$ strongly agree), respondents were requested to indicate their level of agreement with each of the statements.

\section{Selection of Participants}

Ideally, samples are selected to represent the population of interest (Tabachnick \& Fidell, 2007). For the purpose of this study, the population of interest is the accounting students at three MARA institutions. The sample is collected from University Kuala Lumpur Business School (UniKL BIS), Kolej Poly-Tech Mara (KPTM) and Kolej Professional Mara (KPM) students. To ensure that the respondents came from the group of respondents, this study employs an appropriate method in selecting the population by individually contacting these institutions. The total population of the current study is derived to be 2,050 as shown in Table 1.

Table 1: Total Population of the Study

\begin{tabular}{lc}
\hline Gross Population in UniKL Business School & Number of Respondents \\
Gross Population in Kolej Poly-Tech Mara - Cheras & 1,100 \\
Gross Population in Kolej Professional Mara - Beranang & 500 \\
& 450 \\
Total Population & $\mathbf{2 , 0 5 0}$ \\
\hline
\end{tabular}

Hair, Black, Babin, Anderson and Tatham (2006) highlight in their study that researchers need to be fully aware of the impact of sample size on the statistical test. Krejcie and Morgan (1970), developed a scientific table for determining sample size by taking into account population size. The scientific table suggests a sample size of 274 and 278 for a given population of 950 and 1,000 respectively. Alternatively, Roscoe (1975), argues that a sample size of more than 30 and less than 500 is appropriate for most research.

The views presented above suggest that a sample size of anywhere between 274 and 278 is adequate and the current study considers a sample size of 1,000 (i.e. 49 percent of the total population) to be reasonable. This study uses random sampling technique to obtain a representative sample. The population and sampling frame of the current study is presented in Table 2.

Table 2: Population and Sample Size

\begin{tabular}{lccc}
\hline & $\begin{array}{c}\text { Number of } \\
\text { Respondents }\end{array}$ & $\begin{array}{c}\text { Percentage of } \\
\text { Population }\end{array}$ & Sample Size \\
\hline Total & 2,050 & $49 \%$ & 1,000 \\
\hline
\end{tabular}

\section{Survey Execution}

The data collection period was approximately one month, commencing in middle of May and ending in the middle of June 2016. Most of the questionnaire were personally administered using face-to-face method to the targeted sample. 


\section{Measurements}

\section{Development of the Determinants of Students' Perception towards Intention to Pursue Professional Qualification model}

The conceptual model for this study captures the relationship between the independent and dependent variables. The independent variables for this study are salary, job security or stability, prestige or status, opportunity to advance, advisory received, financial assistance and grit personality. The dependent variable for this study is the intention to pursue professional qualification.

Figure 1, presented in Section 2 shows the conceptual model for this study. This model was derived based on the literature review and problem statement. In this study, based on the conceptual model, there are two types of variables which are dependent variable and independent variables. The dependent variable can be defined as the variable that is observed to change in response to the independent variables. Meanwhile, the independent variables are defined as those variables that are deliberately manipulated to invoke a change in the dependent variables. Changes in the independent variables are expected to give significant result to the dependent variable, which is in this case, relates to 'the intention to pursue professional qualification'.

\section{Measurement of the Determinants of Students' Perception towards Intention to Pursue Professional Qualification}

A regression analysis is carried out to examine the determinants of students' intention to pursue professional qualification. The independent variables included are those relating to salary, job security or stability, prestige or status, opportunity to advance, advisory received, financial assistance and grit. The statement and the size of the independent and dependent variables are presented in Table 3 and 4.

Table 3: Statements Measuring the Determinants of Student's Perception and Grit Personality towards Intention to Pursue Professional Qualification (Independent Variables)

\begin{tabular}{llll} 
Determinant/Factor & \multicolumn{1}{c}{ Measurement (Statement) } & Score (Likert Scale) \\
\hline Salary & 1. & $\begin{array}{l}\text { Professional graduates are paid higher salary than } \\
\text { degree graduates. }\end{array}$ & $\begin{array}{l}\text { Higher scores } \\
\text { indicate } \\
\text { agreement about salary. }\end{array}$ \\
2. & $\begin{array}{l}\text { High salary is the main factor why many choose to } \\
\text { pursue professional exam after graduation. } \\
\text { An accounting graduate can gain higher salary if } \\
\text { he/she has professional qualification. }\end{array}$
\end{tabular}

4. Degree holder are paid less than professional qualification holder.

Job security or stability $\quad \begin{aligned} & \text { The career of a professional accountant is highly } \\ & \text { secured. }\end{aligned}$
2. It is not enough to have degree in accounting for job
3. $\begin{aligned} & \text { Other professional fields are not as stable compared to } \\ & \text { accounting field. }\end{aligned}$

Higher scores indicate greater agreement about job security or stability. 
Opportunity to advance

1.

for promotions.

2. Accounting field is the professional field that provides better training opportunities.

Prestige or status

Advisory received

Financial assistance

Grit
1. Professional qualifications are highly valued by the public.

2. Accountants with professional qualification are more respected than accountants with degree in accounting.

3. Professional qualification and non-professional qualification are valued differently by the public.

1. Your parents are supportive of your ambition to be pursue professional examination.

2. Your lecturers or academic advisor encourage you to pursue professional examination.

1. Financial support from various organizations are available to pursue professional examination.

1. I often set a goal but later choose to pursue a different one.

2. I become interested in new pursuit every few months.

3. My interests change from year to year.

4. I have been obsessed in a certain idea or project for a short time but later lost interest.

5. New idea and new projects sometimes distract me from previous.

6. I have difficulty maintaining my focus on projects that take more than a few months to complete.

7. I have achieved a goal that took years of work.

8. I have overcome setbacks to conquer an important challenge.

9. I finish whatever I begin

10. Setbacks don't discourage me.

11. I am a hard worker.

12. I am diligent.
Higher scores indicate greater agreement about opportunity to advance.

Higher scores indicate greater agreement about prestige or status.

Higher scores indicate greater agreement about advisory received.

Higher scores indicate greater agreement about financial assistant.

Higher scores indicate greater grit about student's intention to pursue professional examination.

Table 4: Statement to link Student's Perception towards Intention to Pursue Professional Qualification (Dependent Variable)

Dependent variable

\begin{tabular}{ll}
\hline $\begin{array}{l}\text { Students intention to pursue } \\
\text { professional qualification }\end{array}$ & $\begin{array}{l}\text { Agreement towards selection to intention to pursue professional } \\
\text { qualification, was obtained via selection between certainly, probably and } \\
\text { unlikely. }\end{array}$
\end{tabular}

\section{Data Analysis}

Data are analysed mainly using descriptive statistics and regression analysis. For this purpose, all data are entered into the Statistical Package for the Social Sciences (SPSS) software. Frequency and means analysis are used mainly in analysing the profile of the respondents, namely institution, age, level of study, year of study, gender, ethnic, current CGPA, parent educational background and SPM result for English paper, while variables influencing MARA 
accounting students' institutions intention to pursue professional qualification are analysed by way of multivariate regressions.

\section{RESULTS AND FINDINGS}

The researcher is fortunate to receive an appropriate number of returned questionnaires. Out of 1,000 questionnaires sent, a total of 345 usable questionnaires are returned, which represents 34.5 percent of the net sampling frame (see Table 5).

Table 5: Sample Frame and Response Rate

\begin{tabular}{lccc}
\hline $\begin{array}{c}\text { Gross Sample } \\
\text { Frame }\end{array}$ & Useable Responses & $\begin{array}{c}\text { Useable Response Rate } \\
\text { (\%) }\end{array}$ \\
\hline Number of Respondents & 1,000 & 345 & 34.5 \\
\hline
\end{tabular}

\section{Demographic Profile of Respondents}

A total of nine questions are included in the survey to identify the respondents' demographic profile. These questions seek to gather information such as respondents' institution, age, level of study, year of study, gender, ethnic, current CGPA, parent educational background and SPM result for English paper. The descriptive analysis on the background of the respondents is discussed in this section.

As shown in Table 6 below, analysis of the respondents' institution indicates that about $72.8 \%$ are students from UniKL Business School, 15.1\% from KPTM and 12.2\% from KPM. Most of the respondents (45.5\%) have a current CGPA between 3.00 and 3.49. In terms of age, majority of respondents are between 21 and 23 years old, representing $22.6 \%$ and $24.3 \%$ of the returned sample respectively. In terms of gender, the respondents are $67.8 \%$ female and $32.2 \%$ male. Malaysia is a multi-cultural country with a main ethnic group, Bumiputra. In this study, 99.1\% of the respondents are Bumiputra and the remaining are non-Bumiputra. Information on the respondents' parents' educational background was also collected and the data showed that 51\% hold SPM or below certificate.

Table 6: Background of respondent

\begin{tabular}{llcc}
\hline Item & Description & Frequency & $\begin{array}{c}\text { Percentage } \\
(\%)\end{array}$ \\
\hline Institution & UniKL Business School & 251 & 72.8 \\
& KPTM & 52 & 15.1 \\
& KPM & 42 & 12.2 \\
Age & 19 & & \\
& 20 & 15 & 4.3 \\
& 21 & 28 & 8.1 \\
22 & 78 & 22.6 \\
& 23 & 72 & 20.9 \\
& 24 & 84 & 24.3 \\
& 25 & 40 & 11.6 \\
& 26 & 25 & 7.2 \\
& & 1 & 0.3
\end{tabular}


Gender

Female

Male

Ethnic

$$
\text { Malay Bumiputra }
$$

Non-Malay Bumiputra

Others

Your current CGPA

$$
\begin{aligned}
& \text { Below } 2.00 \\
& 2.00-2.49 \\
& 2.50-2.99 \\
& 3.00-3.49 \\
& 3.50-4.00
\end{aligned}
$$

Parent educational background

$\begin{array}{lcc}\mathrm{A}+ & 9 & 2.6 \\ \mathrm{~A} & 61 & 17.7 \\ \mathrm{~A}- & 16 & 4.6 \\ \mathrm{~B}+ & 41 & 11.9 \\ \mathrm{~B} & 104 & 30.1 \\ \mathrm{C}+ & 17 & 4.9 \\ \mathrm{C} & 17 & 18.6 \\ \mathrm{D} & 64 & 9.0 \\ \mathrm{E} & 31 & 0.6\end{array}$

Table 7 below are the results of descriptive analysis on the second section of the questionnaire. In this section, the respondents are asked about their future plan after graduation. Based on the survey, more than $60.9 \%$ respondents choose to work immediately after graduation and $34.2 \%$ choose to further study. Additionally the respondents are also asked of their intention to pursue professional accounting course and about $96.3 \%$ of the respondents have the intention to at least probably pursue professional qualification. The survey also highlights that $\mathrm{ACCA}^{4}$ is the

\footnotetext{
${ }^{4}$ Association of Chartered Certified Accountants. 
program of choice for these respondents $(82.6 \%)$ and that more than $63.5 \%$ of respondents became aware of the professional programmes from their lecturers.

Table 7: Future plan after graduation

\begin{tabular}{|c|c|c|c|}
\hline Item & Description & Frequency & $\begin{array}{c}\text { Percentage } \\
(\%)\end{array}$ \\
\hline \multirow[t]{3}{*}{ Planning after graduation } & To work immediately & 210 & 60.9 \\
\hline & To further study & 118 & 34.2 \\
\hline & Others & 17 & 4.9 \\
\hline \multirow{3}{*}{$\begin{array}{l}\text { **Intention to pursue professional } \\
\text { qualification }\end{array}$} & Certainly & 132 & 38.3 \\
\hline & Probably & 200 & 58.0 \\
\hline & Unlikely & 13 & 3.8 \\
\hline \multirow{6}{*}{$\begin{array}{l}\text { Preferred professional } \\
\text { programmes to pursue }\end{array}$} & ACCA & 285 & 82.6 \\
\hline & CIMA & 14 & 4.1 \\
\hline & MICPA & 10 & 2.9 \\
\hline & CPA Australia & 22 & 6.4 \\
\hline & ICAEW & 3 & 0.9 \\
\hline & Others & 11 & 3.2 \\
\hline \multirow[t]{7}{*}{$\begin{array}{l}\text { Knowledge of the professional } \\
\text { programmes }\end{array}$} & $\begin{array}{l}\text { From lecturers and academic advisor at your } \\
\text { institution }\end{array}$ & 219 & 63.5 \\
\hline & Seminar/workshop/exhibition & 31 & 9.0 \\
\hline & Career guide from counselling unit & 18 & 5.2 \\
\hline & Advertisement from newspaper & 11 & 3.2 \\
\hline & Notice board at university & 9 & 2.6 \\
\hline & From faculty and friends & 50 & 14.5 \\
\hline & Others & 7 & 2.0 \\
\hline
\end{tabular}

\section{Assessment of Reliability and Validity}

As presented in Section 3, respondents were asked to state their perception towards 27 attitudinal statements that may or may not influence the students' intention to pursue professional qualification. All these statements are grouped into seven aspects: salary, job security or stability, prestige or status, opportunity to advance, advisory received, financial assistance and grit personality. For the measurements of salary, job security or stability, prestige or status, opportunity to advance, advisory received and grit personality which utilised more than one item for each aspect, both reliability and validity test was performed.

The measurements used in this study are considered reliable and consistent as the alpha coefficients were above the acceptable value of 0.6 (Nunnally, 1978; Hair et al., 2006; Sekaran, 2003) as shown in Table 8. 
Table 8: Reliability Coefficient of Determinants of Students Perception

\begin{tabular}{lcc}
\hline Determinant/Factor & Number of Items & Alpha Coefficients \\
\hline Salary & 4 & 0.787 \\
Job Security or stability & 3 & 0.608 \\
Opportunity to advance & 3 & 0.668 \\
Prestige or status & 2 & 0.722 \\
Advisory received & 2 & 0.669 \\
Financial Assistance & 1 & - \\
Grit & 12 & 0.606 \\
\hline
\end{tabular}

\section{Analysis of the Variables}

Relationship between Salary, Job Security or Stability, Prestige or Status, Opportunity to Advance, Advisory Received, Financial Assistance, Grit Personality and Students' Intention to Pursue Professional qualification

This section provides the analysis of the relationship between independent variables with the students' intention to pursue professional qualifications. A regression analysis was carried out to examine the determinants of students' intention. The independent variables for this analysis consist of seven variables: salary, job security or stability, prestige or status, opportunity to advance, advisory received, financial assistance and grit personality. The equation for the proposed regression model is depicted in Equation 1:

\section{Equation 1: Regression Analysis Model to Examine Student's Intention to Pursue Professional Qualification}

$$
\mathrm{Y}=\beta_{0}+\beta_{1}\left(\mathrm{X}_{1}\right)+\beta_{2}\left(\mathrm{X}_{2}\right)+\beta_{3}\left(\mathrm{X}_{3}\right)+\beta_{4}\left(\mathrm{X}_{4}\right)+\beta_{5}\left(\mathrm{X}_{5}\right)+\beta_{6}\left(\mathrm{X}_{6}\right)+\beta_{7}\left(\mathrm{X}_{7}\right)+\mathrm{e}
$$

Where:

$\mathrm{Y}=$ students' intention to pursue professional qualification,

$\mathrm{X} 1=$ salary,

$\mathrm{X} 2=$ job security or stability,

$\mathrm{X} 3=$ opportunity to advance,

$\mathrm{X} 4=$ prestige or status,

$\mathrm{X} 5=$ advisory received,

$\mathrm{X} 6=$ financial assistance,

$\mathrm{X} 7=$ grit, and

e $=$ error.

Assessment of the assumptions using the regression model showed that the model did not violate any of the four assumptions of normality, linearity, multicollinearity and heteroscedasticity. A summary of results for the regression analysis to examine students' intention to pursue professional qualification is presented in Table 9 below. 


\section{Students' Intention to Pursue Professional Qualification}

The regression model is statistically significant $(p=0.003)$ in relation to students' intention to pursue professional qualification. All predictor variables explained about 6.3 percent of the variability of students' intention to pursue professional qualification and were accounted for as the independent variables in this model. Equation 1 also describes the formulation of the multiple regression analysis for the seven independent variables. Out of seven, only three variables, namely job security or stability (Beta $=0.140$ and $\mathrm{p}=0.038)$, financial assistance $($ Beta $=-0.119$ and $p=0.040)$ and grit personality $($ Beta $=-0.123$ and $p=0.025)$ were found to be significant determinants of students' intention to pursue professional qualification. As for the other variables, namely salary, prestige or status, opportunity to advance and advisory received; these were not found to be significant determinants toward the students' intention to pursue professional qualifications.

Table 9: Summary of Results of Multiple Regressions - Students' Perception of the Accounting Profession, Advisory Received, Financial Assistance and Grit personality towards their Intention to Pursue Professional Qualification

\begin{tabular}{lccccc}
\hline & B & SE & Beta & F-value & P-value \\
\hline Salary & -0.078 & 0.062 & -0.085 & -1.270 & 0.205 \\
Job security or stability & -0.119 & 0.057 & -0.140 & -2.088 & $0.038^{*}$ \\
Opportunity to advance & 0.067 & 0.064 & 0.074 & 1.057 & 0.291 \\
Prestige or status & 0.019 & 0.063 & 0.021 & 0.295 & 0.768 \\
Advisory received & 0.086 & 0.052 & 0.100 & 1.664 & 0.97 \\
Financial assistance & 0.079 & 0.038 & 0.119 & 2.061 & $0.040^{*}$ \\
Grit & 0.157 & 0.0694 & 0.123 & 2.254 & $0.025^{*}$ \\
\hline
\end{tabular}

Model Summary: $\mathrm{R}^{2}=0.063 ;$ Adjusted $\mathrm{R}^{2}=0.043 ; \mathrm{F}(345)=3.224 ; \mathrm{p}(0.003)<0.05$

*Significance level is at $p<0.05$.

\section{CONCLUSION}

Despite significant interest in the profession, not many especially the Bumiputra graduates have continued to pursue professional qualifications. This is evidenced by the low percentage of Bumiputra professional accountants registered with MIA. As such this research is conducted to better understand this predicament. This study is undertaken specifically to understand how the perception of accounting students' towards accounting profession, advisory received, financial assistance and grit personality would affect their intention to pursue professional qualifications.

With the sample of the study comprising accounting students from MARA institutions who are mainly of Bumiputra ethinicity, the findings show that all predictor variables explain about 6.3 percent of the variability of students' intention to pursue professional qualification. Further analysis also shows that out of seven independent variables included in this study, only three independent variables have direct significant relationship with a student's intention to pursue professional qualification. These are job security or stability, financial assistance and grit personality. Many previous studies supports the significance of job security and stability to be a factor in students pursuing career as accountants (Mustapha and Abu Hassan, 2012; Abdullah and Zakaria, 2006; van Zyl and de Villiers, 2011; Myburgh, 2005). And financial assistance has also been cited as a significant factor in becoming a chartered accountant for black students 
at a university in South Africa by Myburgh (2005). Grit personality holds a direct significant relationship with a student's intention to pursue professional qualification also as expected.

Other than the main findings, based on the data collected, there are a few other findings and limitations of this study that are worth highlighting. Firstly, virtually all $(96.3 \%)$ of the respondents stated that they would at least probably pursue professional qualification. However, only $38.3 \%$ were certain of it. Majority of the repondents showed interest but are noncommittal.

This study also has its limitations. Firstly, it is recognised that in this study, accounting students of different cohorts are treated as a homogeneous group. As such, the sample under study may not be as accurately representative of its population as it can be. Secondly, although the study finds that all predictor variables explain about 6.3 percent of the variability of students' intention to pursue professional qualification, the much smaller adjusted R-squared of the regression analysis implies room for improvement. Thus, future study may examine other variables such as culture, intrinsic motivation and internship experience of students.

Despite these limitations, it is hoped that the findings of this study will contribute towards further effort and research to improve the percentage of professionally qualified accountants in Malaysia, especially the percentage of professionally qualified Bumiputra accountants.

\section{REFERENCES}

Abdullah, M., \& Zakaria, Z. (2006). Desired attributes of public accounting firms from accounting students' perceptions: the case of University of Malaya \& International Islamic University of Malaysia. Journal of Financial Reporting and Accounting, 4, 2537.

Ahmad, Z., Ismail, H., \& Anantharaman, R.N. (2015). To be or not to be: an investigation of accounting students' career intentions. Education + Training, 57, 360-376.

Babbie, E. R. (2013). The basics of social research. Cengage Learning.

Bacanli, F. (2006). Personality characteristics as predictors of personal indecisiveness. Journal of Career Development, 32(4), 320-332.

Basaruddin, N. (2015). Akauntan bertauliah bumiputera kritikal. [online] Available from: http://www.utusan.com.my/berita/nasional/akauntan-bertauliah-bumiputera-kritikal$\underline{1.143460}$ [Accessed 8th August 2016].

Department of Statistics Malaysia Online Portal (2011). Population Distribution and Basic Demographic Characteristic Report 2010 (Updated: 05/08/2011). [online] Available from:

https://www.statistics.gov.my/index.php? $\mathrm{r}=$ column/cthemeByCat\&cat $=117 \&$ bul $\mathrm{id}=\mathrm{M}$ DMxdHZjWTk1SjFzTzNkRXYzcVZjdz09\&menu id=L0pheU43NWJwRWVSZklWd zQ4TlhUUT09

[Accessed 8th August 2016]. 
Duckworth, A. L., \& Peterson, C. (2007). Grit: Perseverance and passion for long-term goals. Journal of Personality and Social Psychology, 92, 1087-1101.

Germanou, E., Hassall, T., \& Tournas, Y. (2009). Students' perceptions of accounting profession: work value approach. Asian Review of Accounting, 17,136-148.

Ghani, E. K., Said, J., Mohd Nasir, N., \& Jusoff, K. (2008). The 21st century accounting career from the perspective of the Malaysian university students. Asian Social Science, 4, 73 83.

Gunkel, M., Schlaegel, C., Langella, I. M., \& Peluchette, J. V. (2010). Personality and career decisiveness. Personnel Review, 39, 503-524.

Hair, J. F., Black, W. C., Babin, B. J., Anderson, R. E. \& Tatham, R. L. 2006. Multivariate Data Analysis. Sixth Edition. Pearson International Edition, New Jersey.

Jackling, B., de Lange, P., Phillips, J., \& Sewell, J. (2012). Attitudes towards accounting: differences between Australian and international students. Accounting Research Journal, $25,113-130$.

Krejcie, R. V. \& Morgan, D. W. (1970). Determining sample size for research activities. Educational and psychological measurement. 30. p. 607-610.

Law, P. K. (2010). A theory of reasoned action model of accounting students' career choice in public accounting practices in the post-Enron. Journal of Applied Accounting Research. $11,58-73$.

Loo, E. C. (2006). The influence of the introduction of self assessment on the compliance behaviour of individual taxpayers in Malaysia. Ph.D Thesis, University of Sydney.

McKerchar, M. A. (2008). Philosophical paradigms, inquiry strategies and knowledge claims: applying the principles of research design and conduct to taxation. Inquiry Strategies and Knowledge Claims: Applying the Principles of Research Design and Conduct to Taxation, 5-22.

Mustapha, M. \& Abu Hassan, M. H. (2012). Accounting students' perception on pursuing professional eaxamination. International Journal of Education, 4, 1-15.

Myburgh, J. E. (2005). An empirical analysis of career choice factors that influence first-year accounting students at the University of Pretoria. Meditari Accountancy Research, 13, $35-48$.

New Straits Times Online (2015). Malaysia needs 60,000 accountants by 2020. [online] Available from: http://www.nst.com.my/news/2015/09/malaysia-needs-60000accountants-2020

[Accessed 16th July 2016]

Nunnally, J. (1978). Psychometric methods. New York: McGraw Hill.

Remenyi, D., Williams, B., Money, A., and Swartz, E. (1998). Doing research in business and management. London, Sage Publications. 
Roscoe, J. T. (1975). Fundamental research statistics for the behavioral sciences [by] John T. Roscoe. New York, NY: Holt, Rinehart and Winston.

Samidi, J. and Tew, Y.H., (1995). The study on the awareness of secondary school students towards accounting as a profession. In Accounting Seminar: Past, Present and Future, Universiti Teknologi Mara.

Said, J., Ghani, E.K., Hashim, A., \& Mohd Nasir, N. (2004). Perceptions towards accounting career among Malaysian undergraduates. Journal of Financial Reporting and Accounting, 2, 17-30.

Sekaran, U. (2003). Research methods for business: A skill approach. New Jersey: John Willey and Sons, Inc.

Sugahara, S. and Boland, G., (2006). Perceptions of the certified public accountants by accounting and non-accounting tertiary students in Japan. Asian Review of Accounting, 14(1/2), pp.149-167.

Sugahara, S., Hiramatsu, K., \& Boland, G. (2009). The factors influencing accounting school students' career intention to become a Certified Public Accountant in Japan. Asian Review of Accounting, 17, 5-22.

The Star Online (2013). More accountants needed, says MIA chief. [online] Available from: http://www.thestar.com.my/business/business-news/2013/09/17/more-accountantsneeded-says-mia-chief/ [Accessed 16th July 2016].

The Star Online (2015). Govt to boost number of bumiputra accountants. [online] Available from: http://www.thestar.com.my/business/business-news/2015/10/06/govt-to-boostnumber-of-bumiputra-accountants/

[Accesed 16th July 2016].

The Committee to Strengthen the Accountancy Profession. (2014). Report on the strengthening of the accountacy profession in Malaysia.

Trump, G.W., \& Hendrickson, H.S. (1970). Job selection preferences of accounting students. The Journal of Accountancy, June, 84-86.

van Zyl, C., \& de Villiers, C. (2011). Why some students choose to become chartered accountants (and others do not). Meditari Accounting Research, 19, 56-74. 